\title{
СТРУКТУРНО-СЕМАНТИЧНІ ТА КОМУНІКАТИВНО-ПРАГМАТИЧНІ ОСОБЛИВОСТІ ІСПАНОМОВНОГО ІНТЕРНЕТ-СПІЛКУВАННЯ
}

\begin{abstract}
Анотація. Статтю присвячено дослідженню лексико-семантичних та комунікативно-прагматичних особливостей іспаномовного Інтернет- спілкування. Дослідження виконано на матеріалі фрагментів спілкування іспаномовної молоді у найбільш популярних соціальних мережах Інстаграм та Твітер, на форумах, у коментарях під фото чи відео. У рамках роботи також приділено певну увагу вивченню особливостей іспаномовного сленгу. Стаття є спробою дослідження реального спілкування іспаномовної молоді у звичному для них віртуальному середовищі з метою виділення лінгвальних та прагматичних особливостей цього комунікаційного простору.Досліджений емпіричний матеріал дозволив виділити ряд особливостей Інтернет-спілкування іспаномовної молоді, серед яких помічено: нехтування орфографічними, синтаксичними та пунктуаційними правилами; інтенсивне використання паралінгвальних засобів (емотиконів, великих літер, графічних засобів) для вираження і опису емоцій; використання сленгу; вживання табуйованих слів та виразів для інтенсифікації прагматичного ефекту.
\end{abstract}

Ключові слова: Інтернет, Інтернет-комунікація, соціальні мережі, сленг, семантика, прагматика.

Tielkova Oksana, Esperova Valeriia Zaporizhzhia National University

\section{STRUCTURAL-SEMANTIC AND COMMUNICATIVE-PRAGMATIC FEATURES OF SPANISH-SPEAKING INTERNET COMMUNICATION}

Summary. The problem of research of virtual communication (especially young people) is paid more and more attention, because it is safe to say that most of the time young people communicate via the Internet: in social networks, forums, in comments under photos or video, etc. This phenomenon allows us to talk about the emergence of a specific communication space with its canons of existence and development. The urgency of the research problem is determined by the fact that today communication in social networks is gaining the most activity among Internet users. Social networks are a means of managing and increasing the circle of acquaintances, maintaining connections with people with whom it is impossible to stay in touch in the real world, a platform for spreading elements of private life, a means of tracking individuals of common interest, and so on. The article describes the structural-semantic and communicative-pragmatic peculiarities of communication among the young people in virtual network. We paid attention to singularity of the Spanish slang which was revealed in analyzed comments of the most popular platforms used by the young of Spain - Instagram and Twitter. This issue needs to be investigated and the collected materials to be systematized and enriched, because the appearance of the new terms and styles of the Internet-communication happens as quickly as the advancement of the modern technologies. It needs to be said that the illustrative material is presented authentically, without any editing, and contains the expressions of invective vocabulary. This paper attempts to illustrate the communication of the young in their comfortable virtual environment in comparison to their real communication. The study of empirical materials gave us the opportunity to single out the set of features of Internet-communication of Spanish-speaking young people, which include the ignoration of rules of orthography, syntax and punctuation, what serves to gain time on messaging. Intensive use of paralingual resources to express and to describe emotions (emoticons) and the title letters allow users of the social media to transmit various emotions and make the message more expressive. The use of slang in the Internet-communication is fraught with the tendency to use the taboo terms and expressions for intensification of the pragmatic effect.

Keywords: Internet, Internet communication, social networks, slang, semantics, pragmatics.

$\Pi$ остановка проблеми. Поява такого феномену як Інтернет призвела до створення особливої специфічної реальності зі своїми канонами. Інтернет стає засобом глобальної комунікації, яка не має кордонів і об'єднує світові інформаційні ресурси в едину систему. Користувачі мережі мають легкий доступ до величезної кількості інформації, що сприяє процесу індивідуалізації цієї нової фрорми соціального середовища. Варто зазначити, що спілкування в Інтернеті відрізняеться від реальної повсякденної комунікації, що зумовлено умовами його масовості та іншими характеристиками. Зважаючи на ці аспекти, спілкування в Інтернеті набуло особливих форм та засобів, які викликають підвищений інтерес серед сучасних вчених.
Аналіз останніх досліджень та публікацій. Інтернет-комунікація $е$ предметом лінгвістичних досліджень кінця XX - початку XXI століть. Теоретичні аспекти, пов'язані з визначенням поняття та жанрів Інтернет-комунікації, їх структурних, семантичних та прагматичних особливостей були окреслені у працях таких вчених, як: Смишляєва О.В., Виноградова Т.Ю., Силаєва В.Л., Кириченко О.О., Ярута О.Г., Попов Д.С., Леонтович O.O., Лисенко С.О., Івлієва О.О., Юр'єва М.Д. та інші. Наприклад, Леонтович О.О. [1] досліджував проблеми віртуального спілкування, Виноградова Т.Ю. [2] - специфіку спілкування в Інтернеті, Попов Д.С. [3] - цінності та соціальні ролі молодих інтернет-користувачів, Силаєва В.Л. [4] займалася створенням профрілю віртуальних особистостей в Інтернеті. 
Варто зазначити, що на матеріалі іспанської мови вже були зроблені спроби дослідження особливостей мережевого дискурсу Юр'євою М.Д. [5] та лінгвістичних особливостей Інтернет-спілкування іспаномовної молоді Івліевою О.О. [6].

Виділення невирішених раніше частин загальної проблеми. Незважаючи на стрімкий розвиток комунікації у мережі Інтернет, лінгвальні та прагматичні особливості іспаномовного Інтернетспілкування досі не стали центральною проблемою у фонддаментальних дослідженнях з мовознавства. Актуальність цього дослідження зумовлюеться необхідністю більш глибокого опису та вивчення структурно-семантичних та комунікативно-прагматичних особливостей віртуального спілкування іспаномовної молоді у соціальних мережах та чатах.

Мета статті. Метою дослідження є вивчення сучасного іспаномовного Інтернет-спілкування та його структурно-семантичних та комунікативно-прагматичних особливостей. Дана мета припускае вирішення наступних завдань: розглянути значення Інтернету як засобу спілкування; визначити поняття сленгу у сучасній лінгвістиці як ключового елементу Інтернет-спілкування; дослідити структурно-семантичні особливості іспаномовного Інтернет-спілкування; дослідити комунікативно-прагматичні особливості іспаномовного Інтернет-спілкування.

Виклад основного матеріалу. Всього за декілька десятиліть мережа Інтернет проникла майже в усі сфрери нашого життя і стала його невід'емною частиною. За даними сайту Statista.com [7] більше половини населення сьогодення $(59,5 \%)$ використовують Інтернет. Миттеве поширення інформації, можливість спілкуватися за допомогою аудіо чи відео, ведення соціальних мереж - все це $є$ рушійною силою розвитку Інтернет-комунікації. Останнім часом проблемі дослідження віртуального спілкування (особливо серед молоді) з лінгвістичної точки зору приділяється все більше уваги, адже можна 3 упевненістю сказати, що більшість часу молодь спілкуеться саме за допомогою Інтернету: у соціальних мережах, на форумах, у коментарях під фоото чи відео, чатах тощо. Цей процес дозволяе говорити про виникнення специфічного комунікаційного простору, оскільки, за словами Іванова В.С., основною функцією Інтернету сьогодні е функція комунікації, а не отримання інформації [8, с. 52]. Схожу думку знаходимо у Якоби I.О., яка говорить про те, що «інтернет можна вважати продовженням середовища проживання людини, де людина має можливість задовольнити свої соціальні потреби, в тому числі комунікаційні» [9, с. 366]. Ми також вважаємо, що функщііонування сфрери Інтернет-комунікаціі має ряд певних особливостей, не схожих на засоби спілкування у реальному світі.

Створення мережі Інтернет призвело до появи віртуального світу зі своїми правилами та канонами. Деякі дослідники, як, наприклад, Галичкіна О.М. [10], Іванов Л.Ю. [11], Лисенко С.О. [12] та інші все частіше говорять про виникнення так званої «третьої форми мови» поряд з усною та письмовою. За визначенням Смишляєвої О.В., віртуальне спілкування - це «процес, що імітуе структуру, функції і результати реальних відносин і взаємних дій людини, через його віртуальні образи» $[13$, с. 20$]$. Таким чином, ми можемо говорити про появу нової форми мови - віртуальної.
Така форма комунікації мае свої специфічні психологічні та сощіальні особливості, наприклад, за Виноградовою Т.Ю. це:

- анонімність, з якої витікають аббективна розкутість, ненормативність;

- відсутність невербальної інфбормацї̈, що змінюе процес комунікації;

- добровільність контактів - користувач має змогу вільно як зав'язувати контакти, так і обривати їх;

- ускладненість емоиійного компонента спіл$к у в а н н я$, але в той же час прагнення до емоційного наповнення тексту через специфічні знаки чи опис словами;

- прагненна до нетипової, ненормативної поведінки, що проявляеться через намагання користувача Інтернету видати себе за іншу людину [2, с. 63].

Тобто, дослідниця говорить про недостатність засобів вираження як про основну проблему спілкування у чаті. Так, спілкуючись онлайн, користувач не має можливості користуватися такими паралінгвальними засобами, як тембр голосу, акцентування необхідної частини висловлювання, емоційного забарвлення, сили голосу, дикції, жестів і міміки. Таким чином, ми можемо говорити про виникнення особливого Інтернет-стилю у віртуальному просторі.

У нашій роботі ми сконцентруемо особливу увагу на комунікативному просторі у соціальних мережах, оскільки це той жанр, який постійно видозмінюеться. Кількість користувачів зростає 3 шаленою швидкістю, а разом з цим зростае час, який вони там проводять. Ми вважаємо, що соціальні мережі мають декілька важливих функцій: 1) інфбормаційну - новини «розлітаються» по світу миттево завдяки цьому засобу поширення інформації, як особистого, так і глобального масштабу; 2) політичну - у багатьох політиків світу е сторінка у соціальних мережах, через які вони повідомляють новини, висловлюють свое бачення тіеї чи іншої проблеми, таким чином формуючи думки своїх «читачів»; 3) економічну - соцмережі є однією 3 кращих платформ для заробітку грошей у першу чергу для їх власників, а також для комерційних організацій, приватних підприемщів тощо. У більшості випадків соцмережі використовуються як площа для створення реклами, яка має величезний успіх завдяки великій аудиторії користувачів.

у соціальних мережах зареєстровані в них користувачі розміщують інформацію про себе і комунікують між собою, встановлюючи соціальні зв'язки. Контент на такому майданчику створюеться безпосередньо самими користувачами. У соціальній мережі вони розміщують різну інформацію про себе за власним вибором: дату народження, ім'я, місце роботи або навчання, свої споживчі переваги, місце проживання, інформацію про свої подорожі і т. ін. Таким чином, профіль користувача сощіальної мережі стає доступним для інших ії учасників, а «підписники» створюють своє представлення про власника сторінки у соцмережі, базуючись на даній інформації. Але у той же час е велика вірогідність того, що ці дані неправдиві, що дозволяе будь-якому користувачу мережі створити «нове Я», сформувати «себе» за своїм бажанням. Усередині соціальної мережі зв'язок здійснюеться за допомогою внутрішньої пошти або обміну повідомленнями в масштабі реального часу (чатах). Також варто зазначити, що бувають як відкриті сторінки, 
так і закриті, що дає змогу регулювати кількість та якість читачів. Найбільш популярними серед соціальних мереж в Іспанії за 2020 рік є: WhatsApp (85\%), Facebook (81\%), YouTube (70\%), Instagram (59\%), Twitter (51\%) та ін. [14].

Розвиток суспільства зумовлюе структурні зміни в усіх сорерах буття людини. Одним з багатьох важливих аспектів людського життя, в якому безпосередньо відображаються всі зміни, є людське спілкування і мова, до якої належать різні фрорми i існування. Унаслідок безперервних змін у суспільстві з'являються нові сленгові одиниці, широко використовувані у мовленні молодих людей, що потребують постійного вивчення та детального аналізу. Сленг використовуеться у мовленні, у художній літературі, у засобах масової інформації: газетах, журналах, телебаченні, на сцені і в рекламі. Сленг також $є$ невід'ємною частиною інтернет-комунікації.

Як стверджуе Ставицька Л.О., зарубіжні вчені інтерпретують сленг як спосіб висловлювання (Фаулер), специфрічу форому мови бродяг (Гріноу та Кіттрідж), форому розмовної мови (Мак-Найт), різновид фрамільярної та розмовної мови (Поттер), незагальноприйняте, недормальне вживання мови (Александер), жартівливу мову (Нозек) тощо. Сама мовознавець визначае сленг як «практично відкриту мовну підсистему ненормативних, стилістично знижених лексико-фрразеологічних одиниць, які виконують експресивну, ощннну (звичайно негативну та евфемістичну функціï $[15$, с. 42]. Отже, ми можемо зробити висновок, що немае одностайної думки щодо поняття сленгу серед лінгвістів.

У словнику Іспанської Королівської Академії визначення сленгу звучить наступним чином: «Lenguaje especial y no formal que usan entre sí los individuos de ciertas profesiones y oficios» (спеціальна, недормальна мова, якою користуються люди у певних профресіях та родах діяльності) [16]. Варто зазначити, що укладачі даного словника ототожнюють поняття «сленг» (jerga) та «арго» (argot). У статтях іспанських дослідників 3 даної лінгвістичної проблеми знаходимо поняття ciberdiscurso juvenil [17], ciberlenguaje juvenil [18; 19], які використовуеться для позначення «Інтернет-сленгу».

Розглядаючи поняття молодіжного Інтернетсленгу ми дійшли висновку, що це сощіальний френомен, що виник у результаті глобального розвитку Всесвітньої мережі, поширений серед молоді 12-30 років, хоча деякі зарубіжні дослідники [18; 20] стверджують, що цією мовою користуються не тільки молоді люди, але й ті, хто хоче приблизитись до них, стати «своїм». Таким чином, ми можемо зробити висновок, що Інтернет-мовлення має свій вплив на більш широкі вікові сектори.

Для аналізу структурно-семантичних та комунікативно-прагматичних особливостей іспаномовної Інтернет-комунікації нами було відібрано 300 коментарів 3 двох найпопулярніших соцмереж Іспанії - Інстаграму та Твіттеру. На нашу думку, саме ці соціальні мережі якнайкраще відображають тенденцї спілкування іспаномовної молоді. Адже у ході нашої пошукової роботи ми виявили, що донедавна популярні блоги та форуми вже відійшли у минуле, зважаючи на малу активність користувачів як у коментарях, так і серед самих авторів. Разом з тим, соціальна мережа Інстаграм, яка початково слугувала лише для поширення, ощінки та постингу фотографій та відеоматеріалів, за останній час перетворилася у майданчик для мікроблогів, просування бізнесу, поширення освіти (вивчення різних іноземних мов) тощо. Кількість користувачів цієї мережі перевищуе 1,16 млрд чоловік (на 2020 рік), з яких 20 млн приходиться на Іспанію [21]. На другому місці після Інстаграму знаходиться сощіальна мережа Твіттер з 53\% користувачів Інтернету, зареєстрованих на даному майданчику [21].

За результатами аналізу фрактичного матеріалу нами було виділено такі структурно-семантичні особливості іспаномовного інтернет-спілкування:

1) використання префіксу súper (super chulas);

2) використання суфріксів:

- зменшувально-пестливих -ito, -ico (chikito, pincelico) та зміни закінчення на -i (moniiis, porfi);

- збільшувальних суфіксів -ón, -azo (muñecón, modelaza, cuerpazo).

Серед орфографічних особливостей нами було виділено:

1) випускання літери $d$ у прислівниках і дієприкметниках із закінченням -ado: demasiao, rayaо;

2) зміна gua на w: guapísimo - wapisimo;

3) випущення $h$ як німої літери: hago - ago; ahora-aora;

4) скорочення слів до тієї кількості знаків, яка фонетично передає зміст слова: $q$ (que), sq (es que);

5) абревіація: $B B$ (bebé), HDSPM (hijo de su puta madre);

6) акроніми: tmb (también), dnd (donde);

7) скорочення слів: porfa (por favor), finde (fin de semana);

8) використання принципу «як чую, так і пишу»: la berdá = la verdad;

9) заміна слова за принципом подібного звучання, що призводить до граматичних помилок: has - haz, ves - vez.

Серед лексичних особливостей нами були виділене широке використання сленгу: іменників (piltrafilla, pedazo); якісних прикметників (chulo, flipante); дієслів (flipar, petar); стійких словосполучень (ser la leche, pasarse tres pueblos); англіцизмів (ready, crack, hater), у тому числі абревіатур (Pov) та гібридних dpopм (supermanes, porfaplis); вигуків (jEa!, ;Buah!). Сленг іспаномовної молоді характеризуеться використанням інвективних: іменників (puta, coño); прикметників (chingado, jodido); дієлів (joderse, cagarse), прислівників (a hostias, jodidamente) та дієприкметників (cabreado, acojonado); сталих виразів деспективного забарвлення (estar hasta los cojones, cagarla parda).

Серед комунікативно-прагматичних особливостей комунікації у мережі Інтернет нами було виділено наступні:

1. Збільшення кількості літер задля більшої експресивності повідомлення (Jamaaaaas me tapo en veranooo que caloooooor almenos en mi habitacion).

2. Використання абревіащії - випущення голосних букв, що зумовлено бажанням пришвидшити процес спілкування (donde - dnd, es que $e s q$, verdad - vdd, $t-t e$, no sé - ns).

3. Різні способи передачі сміху:

- вербальний (Jajajajajajajajjajaja tan yo, $J A J A J A J)$.

Іноді можна помітити, що у процесі написання користувач мережі використовуе неправильний порядок літер або навіть інші літери, що 
знаходяться поруч (ЈAЈJЈАЈЈАЈJAJAЈAJAKSK SKSKSJKKAKSJS).

Ще одне звуконаслідувальне слово (ономатопея), що широко використовуеться на просторах електронного спілкування, створюеться додаванням початкових літер, які передають нестримний та різкий прояв сміху (Buajajajajajajajajajajajja). На нашу думку, це зумовлено прагненням показати реальність своїх емоцій.

Також ми виділили дієслова, що передають нестримний сміх: me ahogo, me meo, estoy por el suelo. Абревіатура 3 англійської мови lol (laughing out loud - cлiюcь у весь голос) також часто зустрічаеться для позначення нестримного сміху серед іспаномовної молоді.

- невербальний, що реалізується за допомогою емотиконів (емодзі). Використання емотиконів дає змогу краще виразити свої емоції за рахунок наочності - чіткого прояву певної емоції. Деколи зустрічаються вербальні позначки емотиконів, наприклад $X D$ позначає людину, що сміється.

- злішаний: використання вербальних та невербальних засобів.

4. В інтернет-спілкуванні іспанської молоді також присутне використання великих букв, що зумовлено прагненням до більшої експресивності, а також задля цілі бути поміченим серед великої кількості коментарів (VAMOOOOOOOOOOOOOOOOOO QUE NUNCA NAREN ESTAS COSAS QUE YA MISMO LA LLEVO AL CINEEEEEEEEE). Таким чином користувач мережі привертає до себе увагу.

5. Серед звертань до співрозмовника ми також виявили сленгові варіанти: tío, hombre, colega, nano, tronco, mama hija, mamacita, mami, pana. Крім того, використовуються деспективні іменники, що вказують на фрізичну чи моральну недовершеність людини: piltrafilla, canijo, esmirriado, plasta, machacón, pringado. Серед позитивно забарвлених звертань ми виявили: $\cos a$, cosita, muñecon, pivón (pibón), piva (piba), diosa.

6. На рівні лексики і стійких словосполучень цікавим $є$ їх емфратичне вживання та гіперболізація. До даної категорії відносяться прикметники і прислівникові вирази, метою яких є інтенсифрікація якості або кількості. 3 метою посилення позитивної оцінки іспаномовна молодь вдається до використання інтенсифікуючих прикметників і прислівників: menudo, mazo, vaya, de molón. Ceред них є багато термінів табу: puto, jodidamente, de hostias. Характерною особливістю іспанського сленгу є використання дисфемізмів: estar hasta los cojones, joderse, ponerse piripi. Дисдемізми ви- конують подвійну експресивну функцію: з одного боку вони передають емоційний стан мовця (роздратування чи невдоволення), з іншого боку, допомагають ідентифрікуватися в компанії, позначити соціальну групу, до якої належить мовець.

7. Для того, щоб підкреслити позитивні якості людини чи будь-чого використовуються такі слова, як:

1) іменники: crack, pedazo, pasada;

2) прикметники: brutal, achuchable, chulada;

3) сталі словосполучення: ser la leche, ser la caña, ser un bombón.

8. Для вираження здивування використовують наступні вигуки: rayos, vaya. Серед них є також нецензурні варіанти: joder, hostias, ostras, no me jodes.

Висновки і перспективи. Досліджений емпіричний матеріал дозволив нам виділити ряд особливостей Інтернет-спілкування іспаномовної молоді: 1) нехтування орфографічними, синтаксичними та пунктуаційними правилами; 2) використання скорочених слів, абревіацій, випускання літер; 3) інтенсивне використання паралінгвальних засобів для вираження і опису емоцій - емотиконів, що дозволяють передати різні емощії («:-)», «:-(» тощо), а також великих літер; 4) використання ономатопеї; 5) широке використання табуйованих слів та виразів для інтенсифрікації мовлення; 6) використання запозичених слів та абревіацій з англійської мови, а також гібридних форм - змішання іспанських та англійських слів.

Інтернет-спілкування зумовлено тяжінням до:

- експресивності повідомлення (різні способи передачі сміху, вигуки, емотикони);

- скорочення часу відповіді за рахунок використання абревіацій, скорочених слів;

- підкреслення негативних якостей людини за рахунок використання деспективних іменників та прикметників;

- підкреслення позитивних якостей людини за допомогою емфратичних та гіперболізованих іменників, прикметників, прислівникових виразів;

- використання дисфемізмів задля підсилення експресивності повідомлення.

Отже, комунікація у мережі Інтернет якнайкраще відображає суспільні зміни у реальному житті, але представляе собою окремий світ віртуального спілкування, який має свої правила, засоби та фрункції.

Перспективним нам видається звернення до вивчення інтернет-комунікації в аспекті регіонального варіювання, оскільки національні варіанти іспанської мови представляють чималий інтерес для сучасних дослідників з огляду на їх специфічні лексико-семантичні риси.

\section{Список літератури:}

1. Леонтович O.А. Проблемы виртуального общения. Полелика. 2000. Выпуск 7. URL: http://www.irex.ru/press/ pub/polemika/07/leo/ (дата звернення: 05.09.2021).

2. Виноградова Т.Ю. Специфика общения в Интернете. Русская и сопоставительная фбллология: Лингвокультурологический аспект. Казань : Казан. гос. ун-т. фрилол. фак-т, 2004. С. 63-67.

3. Попов Д.С. Молодые Интернет-пользователи: противоречие становления ценностей образа жизни : автореф. дисс. ... канд. социол. наук : 22.00.06. Екатеринбург, 2008. 19 с.

4. Силаева В.Л. Интернет как социальный феномен. Социологические исследования. 2008. № 11. С. $101-107$.

5. Юрьева М.Д. Типология и способы репрезентации испанского сетевого текста (на материале чатов и форумов) : автореф. дис. ... канд. фрилол. наук : 10.02.05. Москва, 2014. 22 с.

6. Ивлиева Е.А. Особенности испанской интернет-коммуникации в социальных сетях. Филологические науки. Вопросы теории и практики. 2021. Том 14. Выпуск 1. С. 141-146.

7. Statista.com. URL: https://www.statista.com/ (дата звернення: 04.10.2021).

8. Иванов В.Е. Интернет в формировании диалогического пространства в социокультурной среде. Мup психологии. 2000. № 2. С. 52-56. 
9. Якоба И.А. Особенности интернет-коммуникации (социологический, лингвистический, гендерный аспекты). Вестник ИрГТУ: Гуланитарные науки. 2012. № 3(62). С. 365-371.

10. Галичкина Е.Н. Специфика компьютерного дискурса на английском и русском языках (на материале жанра компьютер. конф.) : автореф. дис. ... канд. филол. наук : 10.02.20. Волгоград, 2001. 19 с.

11. Иванов Л.Ю. Язык в электронных средствах коммуникации. Культура русской речи. Москва : Флинта Наука, 2003. 840 с.

12. Лысенко С.А. Взаимодействие устной и письменной формы существования языка в интернет-коммуникации : авторедр. дисс. ... канд. филлол. наук : 10.02.19. Воронеж, 2010. 24 с.

13. Смышляева Е.В. Социально-педагогические условия организации виртуального общения молодежи : авторефр. дис. ... канд. пед. наук : 13.00.02. Кострома, 2009. 21 с.

14. Estudio Anual de Redes Sociales IAB 2020. URL: https://iabspain.es/estudio/estudio-redes-sociales-2020/ (дата звернення: 18.10.2021).

15. Ставицька Л.О. Арго, жаргон, сленг. Київ : Критика, 2005. 464 с.

16. Diccionario de la lengua española. Edición del Tricentenario. URL: http://dle.rae.es (дата звернення: 19.10.2021).

17. Palazzo M. G. Aspectos comunicativos del ciberdiscurso juvenil. Consideraciones teóricas. Revista Argentina De Estudios De Juventud. 2010. № 1(3). URL: https://perio.unlp.edu.ar/ojs/index.php/revistadejuventud/article/ view/1486 (дата звернення: 20.10.2021).

18. Vaqueiro M. Ciberlenguaje juvenil en las redes sociales. Congreso Iberoamericano de las Lenguas en la Educación y en la Cultura / IV Congreso Leer.es. Salamanca España, 5 al 7 de septiembre de 2012. URL: https://studylib.es/ doc/6029467/ciberlenguaje-juvenil-en-las-redes-sociales (дата звернення: 20.10.2021).

19. Arias D., Ramos T., Núñez L., Inga M. El ciberlenguaje juvenil universitario: Análisis de los textos de la página de Facebook "Confesiones". Propósitos y Representaciones. 2018. № 6(2). P. 339-405. URL: https://www.researchgate.net/ publication/330979531_El_ciberlenguaje_juvenil_universitario_Analisis_de_los_textos_de_la_pagina_de_ Facebook_Confesiones (дата звернення: 20.10.2021).

20. Aguilar P., Inés M. Aproximación a la descripción de las prácticas de escritura vernácula en Internet de estudiantes chilenos de enseñanza superior REXE. Revista de Estudios y Experiencias en Educación. 2017. Vol. 16, núm. 30. P. 99-114.

21. Es.statista.com. URL: https://es.statista.com/temas/3168/panorama-mundial-de-las-redes-sociales/\#dossier Summary_chapter1 (дата звернення: 15.10.2021).

\section{References:}

1. Leontovich O.A. (2000) Problemy virtual'nogo obshcheniya. Polemika, vol. 7. Available at: http://www.irex.ru/ press/pub/polemika/07/leo/ (accessed 9 September 2021). (in Russian)

2. Vinogradova T.Yu. (2004) Specifika obshcheniya v Internete. Russkaya $i$ sopostavitel'naya filologiya: Lingvokulturologicheskij aspekt. Kazan', pp. 63-67. (in Russian)

3. Popov D.S. (2008) Molodye Internet-pol'zovateli: protivorechie stanovleniya cennostej obraza zhizni: avtoref. dis. ... kand. sotsiol. nauk: 22.00.06. Ekaterinburg, 19 p. (in Russian)

4. Silaeva V.L. (2008) Internet kak social'nyj fenomen. Sociologicheskie issledovaniya, vol. 11, pp. 101-107. (in Russian)

5. Yur'eva M.D. (2014) Tipologiya i sposoby reprezentacii ispanskogo setevogo teksta (na materiale chatov i forumov): avtoref. dis. ... kand. filol. nauk: 10.02.05. Moskow, 22 p. (in Russian)

6. Ivlieva E.A. (2021) Osobennosti ispanskoj internet-kommunikacii v social'nyh setyah. Filologicheskie nauki. Voprosy teorii i praktiki, vol. 14, no. 1, pp. 141-146. (in Russian)

7. Statista.com. Available at: https://www.statista.com/ (accessed 4 November 2021).

8. Ivanov V.E. (2000) Internet v formirovanii dialogicheskogo prostranstva v sociokul'turnoj srede. Mir psihologii, no. 2, pp. 52-56. (in Russian)

9. Yakoba I.A. (2012) Osobennosti internet-kommunikacii (sociologicheskij, lingvisticheskij, gendernyj aspekty). Vestnik IrGTU: Gumanitarnye nauki, vol. 3(62), pp. 365-371. (in Russian)

10. Galichkina E.N. (2001) Specifika komp'yuternogo diskursa na anglijskom i russkom yazykah (na materiale zhanra komp'yuter. konf.): avtoref. dis. ... kand. filol. nauk: 10.02.20. Volgograd, 19 p. (in Russian)

11. Ivanov L.Yu. (2003) Yazyk v elektronnyh sredstvah kommunikacii. Kul'tura russkoj rechi. Mosow: Flinta Nauka, 840 p. (in Russian)

12. Lysenko S.A. (2010) Vzaimodejstvie ustnoj i pis'mennoj formy sushchestvovaniya yazyka v internet-kommunikacii: avtoref. dis. ... kand. filol. nauk: 10.02.19. Voronezh, $24 \mathrm{p}$.

13. Smyshlyaeva E.V. (2009) Social'no-pedagogicheskie usloviya organizacii virtual'nogo obshcheniya molodezhi: avtoref. dis. ... kand. ped. nauk: 13.00.02. Kostroma, $21 \mathrm{p.}$

14. Estudio Anual de Redes Sociales IAB 2020. Available at: https://iabspain.es/estudio/estudio-redes-sociales-2020/ (accessed 18 November 2021).

15. Stavytska L.O. (2005) Argo, zharhon, slenh. Kyiv: Krytyka, 464 p. (in Ukrainian)

16. Diccionario de la lengua española. Edición del Tricentenario. Available at: http://dle.rae.es (accessed 19 November 2021).

17. Palazzo M.G. (2010) Aspectos comunicativos del ciberdiscurso juvenil. Consideraciones teóricas. Revista Argentina De Estudios De Juventud, no. 1(3). Available at: https://perio.unlp.edu.ar/ojs/index.php/revistadejuventud/ article/view/1486 (accessed 20 November 2021).

18. Vaqueiro M. juvenil en las redes sociales. Congreso Iberoamericano de las Lenguas en la Educación y en la Cultura / IV Congreso Leer.es. Salamanca España, 5 al 7 de septiembre de 2012. Available at: https://studylib.es/ doc/6029467/ciberlenguaje-juvenil-en-las-redes-sociales (accessed 20 October 2021).

19. Arias D., Ramos T., Núñez L., Inga M. (2018) El ciberlenguaje juvenil universitario: Análisis de los textos de la página de Facebook "Confesiones". Propósitos y Representaciones, no. 6(2), pp. 339-405. Available at: https://www.researchgate.net/publication/330979531_El_ciberlenguaje_juvenil_universitario_Analisis_de_los_ textos_de_la_pagina_de_Facebook_Confesiones (accessed 20 October 2021).

20. Aguilar P., Inés M. (2017) Aproximación a la descripción de las prácticas de escritura vernácula en Internet de estudiantes chilenos de enseñanza superior REXE. Revista de Estudios y Experiencias en Educación, vol. 16, núm. 30, pp. 99-114.

21. Es.statista.com. Available at: https://es.statista.com/temas/3168/panorama-mundial-de-las-redes-sociales/\#dossier Summary_chapter1 (accessed 15 October 2021). 